UC-350

\title{
Buildings Energy Program Annual Report FY 1991
}

May 1992

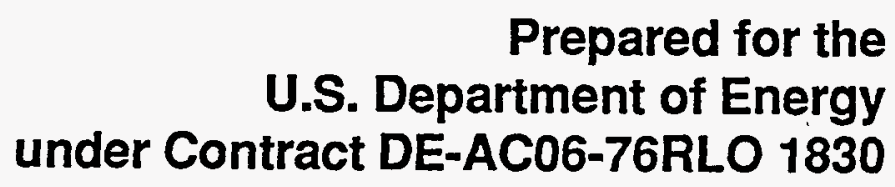

Pacific Northwest Laboratory Richland, Washington 99352 

Pacific

Northwest Laboratory

B

Energy Program

Annual Report
RECEIVED

JUL 131994

OSTI

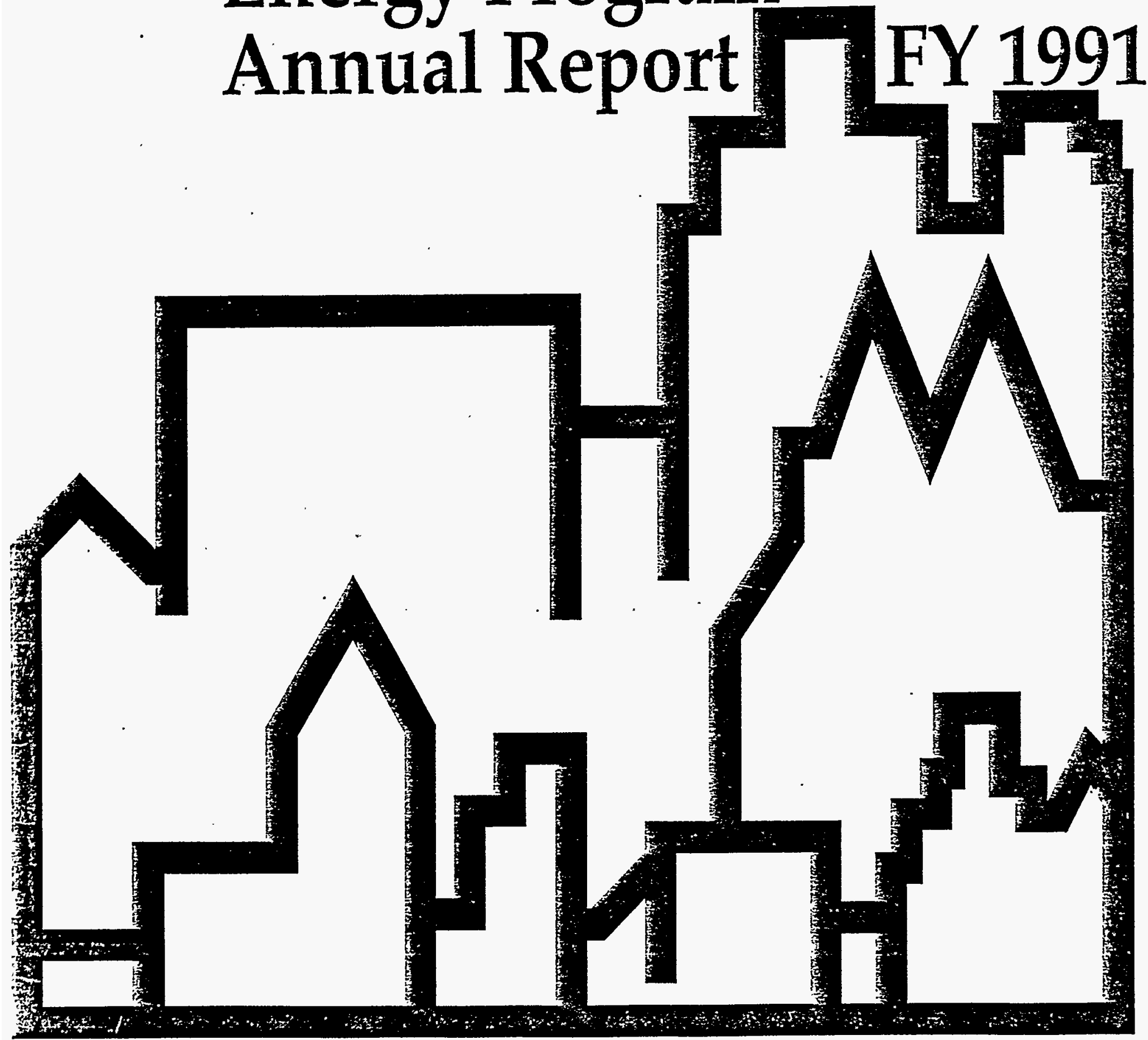

Prepared for the U.S. Department of Energy under Contract DE-AC06-76RLO 1830 


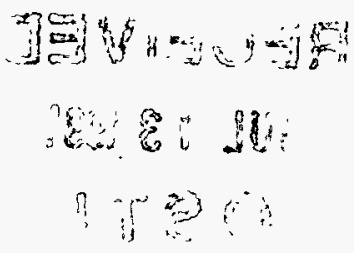

\title{
DISCLAIMER
}

This report was prepared as an account of work sponsored by an agency of the United States Government. Neither the United States Government nor any agency thereof, nor Battelle Memorial Institute, nor any of their employees, makes any warranty, expressed or implied, or assumes any legal liability or responsibility for the accuracy, completeness, or usefulness of any information, apparatus, product, or process disclosed, or represents that its use would not infringe privately owned rights. Reference herein to any specific commercial product, process, or service by trade name, trademark, manufacturer, or otherwise does not necessarily constitute or imply its endorsement, recommendation, or favoring by the United States Government or any agency thereof, or Battelle Memorial Institute. The views and opinions of authors expressed herein do not necessarily state or reflect those of the United States Government or any agency thereof.

\author{
PACIFIC NORTHWEST LABORATORY \\ operated by \\ BATTELLE MEMORIAL INSTITUTE \\ for the \\ UNITED STATES DEPARTMENT OF ENERGY \\ under Contract DE-ACO6-76RLO 1830
}

Printed in the United States of America.

Available to DOE and DOE contractors from the

Office of Scientific and Technical Information, P.O. Box 62, Oak Ridge, TN 37831; prices available from (615) 576-8401. FTS 626-8401.

Available to the public from the National Technical Information Service, U.S. Department of Commerce, 5285 Port Royal Rd., Springfield, VA 22161.

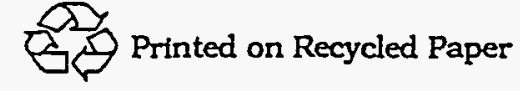




\section{Buildings Energy Program}

Pacific Northwest Laboratory (PNL) is one of nine U.S. Department of Energy (DOE) multiprogram laboratorles that assist DOE and other organizations in solving scientific and technical problems. The underlying philosophy at PNL is to develop and transfer scientific and engineering innovations to industry and government. PNL is operated for DOE by Battelle Memorial Institute.

The Bulldings Energy Program at PNL conducts research and development (R\&D) for DOE's Office of Building Technologies (OBT). The OBT's mission is to lead a national program supporting private and federal sector efforts to improve the energy efficiency of the nation's buildings and to increase the use of renewable energy sources. Under an arrangement with DOE, Battelle staff also conduct research and development projects for other federal agencies and private clients. This annual report contains an account of the buildings-related research projects conducted at PNL during flscal year (FY) 1991.

A major focus of PNL's energy projects is to improve the energy efficiency of commercial and residential buildings. Researchers who are developing solutions to energy-use problems view a bullding as an energy-using system. From this perspective, a desirable solution is not only one that is cost-effective and responsive to the needs of the occupants, but also one that optimizes the interaction among the energy components and systems that compose the whole.

Developing such solutions requires a detailed understanding of several factors:

n the individual performance of energy conversion and envelope technologies and their interactions when they are assembled into an energy-úsing system (building)

- the interaction between the occupants and the building system the relationships between and among buildings and their associated energy supply systems as these buildings are aggregated into community systems.

Understanding these factors requires the knowledge of many disciplines. PNL's program draws on the expertise of staff from the bullding, thermal, computational, and social sciences. These staff analyze and assess energy use in buildings, develop "systems" of energy technologies, and measure the actual performance of individual technologies and systems as they are used.

In FY91, projects ranging from several thousand to over two million dollars were conducted for DOE, DOE's Bonneville Power Administration (Bonneville), other federal agencies, and private clients.

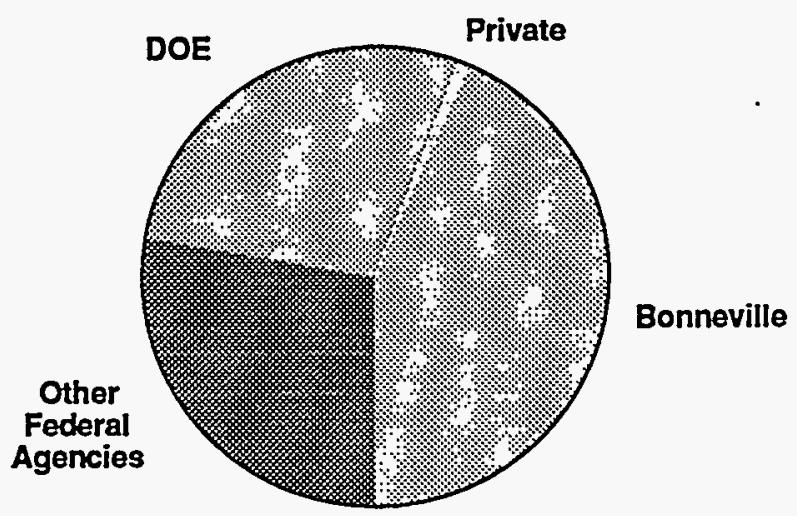

Of $\$ 20.7$ million of research in FY91, DOE funded 28\%, Bonneville 43\%, other federal agencies $28 \%$, and private clients $1 \%$.

The following pages present an overview of projects conducted for each of these clients, as well as highlights from projects to deploy technologies, to develop cooperative research programs with universities, and to support PNL's internally funded energy initiative. 



\section{Contents}

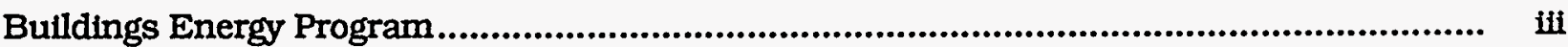

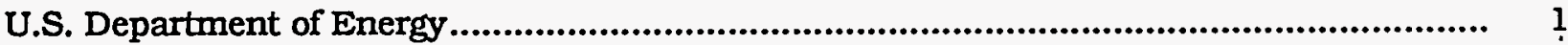

Building System Integration Program .................................................................

Building Energy Standards Program ........................................................................... 3

Federal Energy Management Program .................................................................... 5

Economics and Systems Analysis Program .............................................................. 7

Bulldings Equipment Technology Assessment Program ............................................. 8

Support to Pacific Gas and Electric Company's ACT ${ }^{2}$ Project ....................................... 8

Bonneville Power Administration ......................................................................... 11

Regional End-Use Metering Program ................................................................. 11

Manufactured Housing Technical Transfer Project ................................................... 12

Residential Fuel Choice Project........................................................................... 13

Evaluation Research Assistance Project ................................................................. 14

Energy Edge Program ....................................................................................... 14

Tacoma Multifamily End-Use Monitoring Project ...................................................... 15

Equivalent Thermal Parameters Project ................................................................... 15

Resource Supply Expansion Program ............................................................. 16

Other Federal Agencies ....................................................................................... 17

Work Through the Federal Energy Management Program ........................................... 17

U.S. Department of Housing and Urban Development............................................... 17

Private Clients............................................................................................. 19

Gas Research Institute ................................................................................ 19

Pennsylvania Power \& Light Company .................................................................... 20

Pacific Gas and Electric Company ......................................................................... 20

National Research Council, Canada ....................................................................... 21

Northwest Power Planning Council ..................................................................... 21

Mineral Insulation Manufacturers Association ..................................................... 22

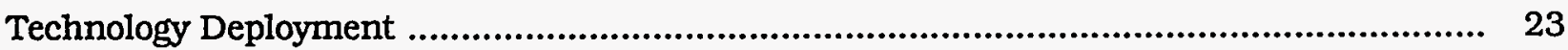

University Relations ....................................................................................... . 25

Energy Technology Development Initiative .............................................................. 27

System Diagnostics and Operations .................................................................... 27

Resource Confirmation .............................................................................. 27 
Bulldings Energy Program

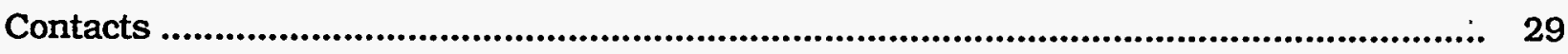

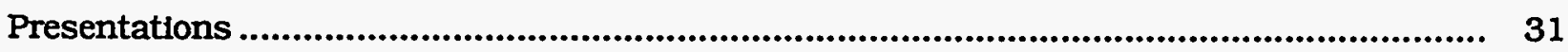

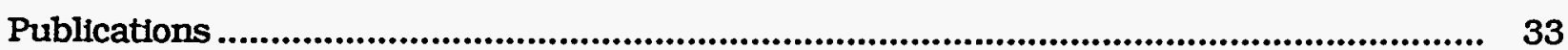

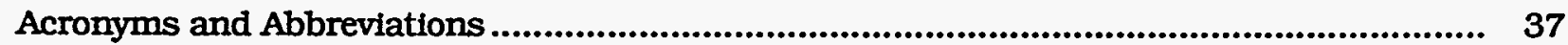




\section{U.S. Department}

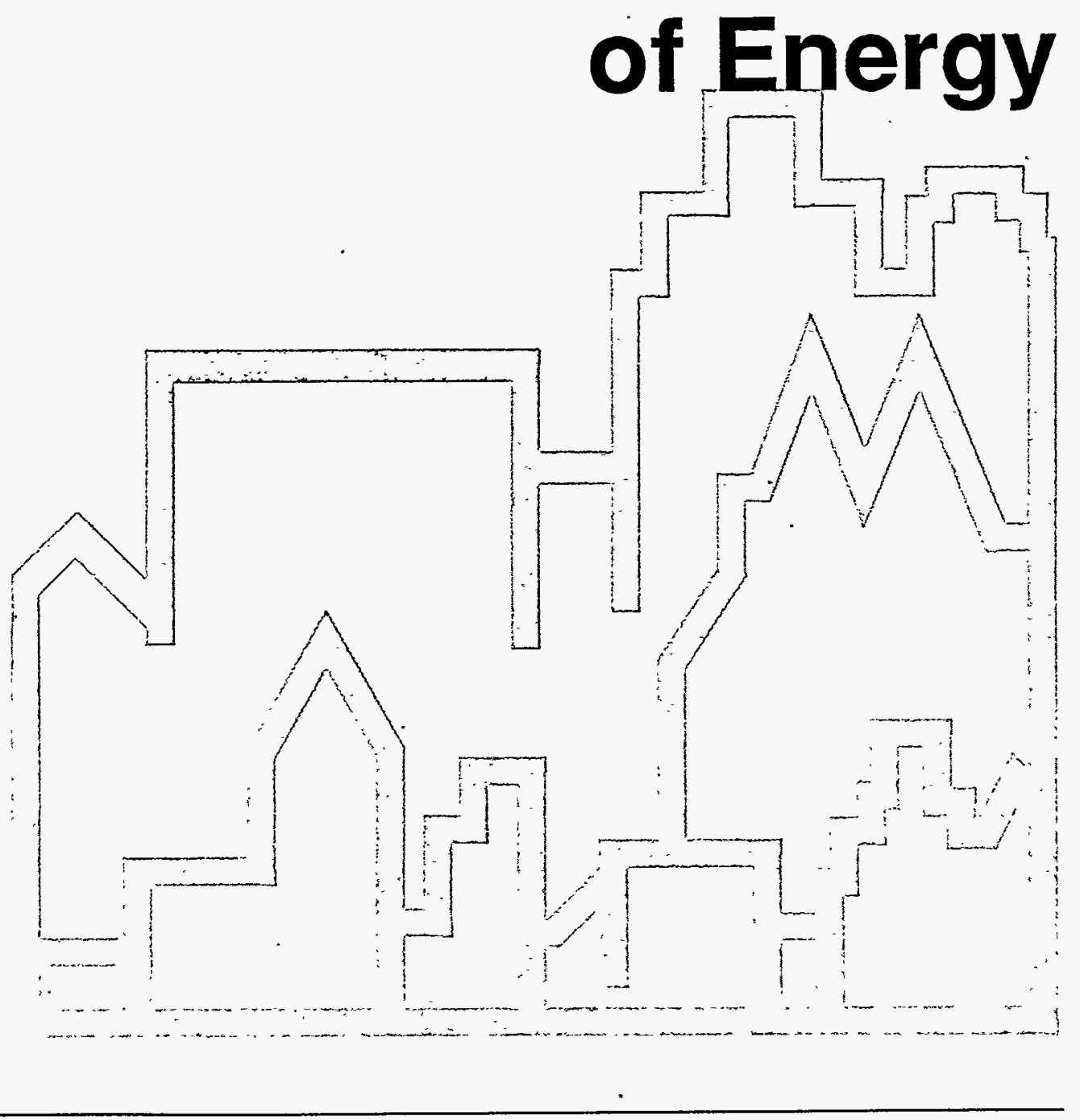





\section{U.S. Department of Energy}

The OBT comprises three offices: the Office of Building Energy Research, the Office of Codes and Standards, and the Office of Federal Energy Management Program (FEMP). PNL conducts R\&D and provides analysis and assessment support for each of these offices, as well as for the OBT as a whole.

\section{Building System Integration Program}

The Building System Integration Program (BSIP) is conducted for OBT's Office of Bullding Energy Research. The BSIP's goal is to improve energy-related decision making during all phases of the building life cycle. The research approach is to view the whole bullding as an energy-using system.

The objectives of BSIP are

a to understand interactions among technologies within the building

- to optimize the combined performance of these technologies when they are integrated into a whole-building system

- to develop, in cooperation with industry, computer-based tools to facilitate the design and operation of energy-efficient buildings.

Expertise and resources from industry, academia, other government entities, and other DOE laboratories are used in planning, reviewing, and conducting research activities. Cooperative efforts with other organizations are an integral component of BSIP.
The major BSIP project activities are

Advanced Energy Design and Operation Technologies

Whole-Building Energy Targets

a Heating, Ventilating, and AirConditioning (HVAC)/Structure Interactions.

\section{Advanced Energy Design and Operation Technologies}

The objective of the Advanced Energy Design and Operation Technologies (AEDOT) Project is to integrate energy-saving expertise into advanced computer-aided design (CAD) and building operation systems. The resulting software will use artificial intelligence, sophisticated computer graphics, and other computer technology to put this expertise at the disposal of architects and engineers who make decisions about energy efficiency as they design, construct, and operate buildings.

The first AEDOT prototype is under development now and is expected to be complete in FY92. It will then be presented to end-user groups, such as the American Institute of Architects, to obtain feedback to guide future development.

During FY91, PNL and the National Institute of Standards and Technology collaborated to begin developing a plan for a major new OBT program component focusing on building operations. A large energy resource is associated with improving the commissioning and operation of new and existing commercial buildings. The new program will focus on developing and deploying technology to capture that resource.

Because DOE wishes to deploy technologies as rapidly as possible, joint ventures with 
industry and with universities are an integral part of the AEDOT Project. PNL is collaborating with Lawrence Berkeley Laboratory, Callfornia Polytechnic State University, and the University of Oregon on the first AEDOT prototype.

PNL also strengthened relationships with industry; these relationships are likely to result in at least one collaborative $R \& D$ project during FY92. In FY92, PNL will initiate a Cooperative Research and Development Agreement (CRADA) for a collaborative effort to integrate simplifled energy analysis capabilities with a commercially available CAD software package.

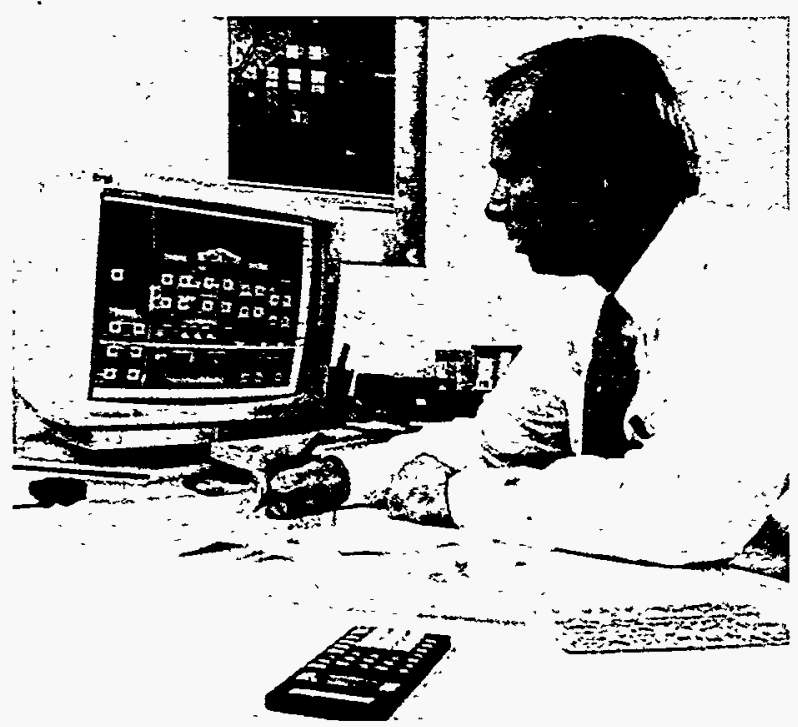

AEDOT Prototype 1 will have capabilities to assist designers with energy-related early conceptual design and daylighting design. It will also help designers comply with building energy standards as the building design evolves.

\section{Whole-Building Energy Targets}

The objective of the Whole-Building Energy Targets Project (Targets) is to develop a methodology for generating energy performance targets for new commercial buildings.
The methodology will provide a key technical basis for future performance-based energy standards and guidelines, retrofit analyses, and technology assessments.

PNL is being assisted in this project by a buildings industry support team composed of representatives from the American Society of Heating, Refrigerating and Air-Conditioning Engineers (ASHRAE); the Iluminating Engineering Society of North America (IES); and the American Institute of Architects/ Associated Collegiate Schools of Architecture Council on Architectural Research.

Efforts during FY91 focused on beginning development of working prototypes to demonstrate, test, and implement the methodology through software. During FY92, PNL will complete the first Targets prototype. The buildings industry will be asked to test the prototype and provide feedback for continued development.

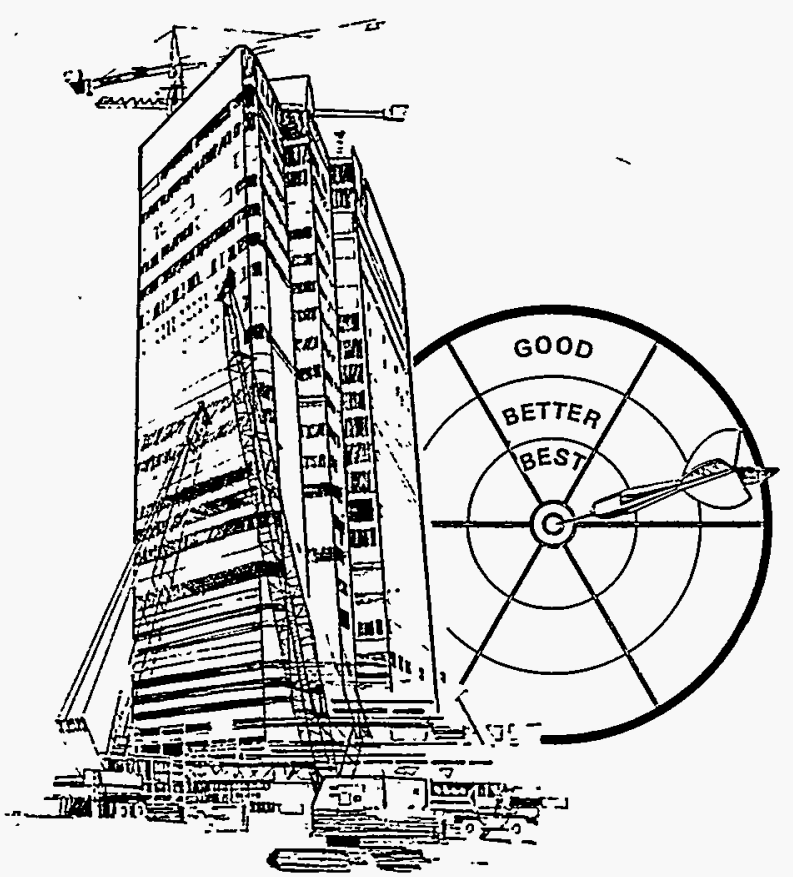

Using the Targets methodology, architects, engineers, and building managers will be able to optimize energy efficiency in buildings. 


\section{HVAC/Structure Interactions}

During FY91, staff from the HVAC/ Structure Interactions Project completed the final report for a study examining the feasibility of combining elements of a building's structure, HVAC equipment, and distribution equipment into an energysaving multifunctional system.

The integrated system comprises four elements: the bullding structure (to store and deliver heat), unitary water-source heat pumps (to condition space and reclaim heat), a cooling tower (to reject heat), and an auxiliary boiler (to add heat). To take advantage of interactions, these four elements are interconnected by a common water loop.

To determine potential energy savings, a $90,000-\mathrm{ft}^{2}$, six-story office building equipped with the integrated system was compared with an identical building that did not have the integrated system (the base case building). 'The analysis showed that, when properly applied, the integrated system saves up to $18 \%$ of the energy used for mechanical cooling.

The integrated system performed best in hot, dry climates. Features that enhance its performance are better controls, the configuration of the hydronic piping circuit, and the physical and thermal properties of the slab.

For more information on the Bullding System Integration Program, contact

Michael R. Brambley 509/375-6875

\section{Building Energy Standards Program}

The Building Energy Standards Program (BESP) is conducted for OBTs Office of Codes and Standards. The BESP is aimed at developing, testing, demonstrating, and implementing energy performance standards for new commercial and residential buildings. PNL's multidisciplinary approach allows the issues surrounding the development and implementation of these standards to be fully examined.

Program staff regularly coordinate and interact with industry and the buildings community to obtain their guidance. The BESP also supports the U.S. Department of Housing and Urban Development (HUD) with the revision of that agency's energy conservation standard for manufactured housing (see page 17).

The BESP has three objectives:

- to develop cost-effective design standards to improve energy efficiency and encourage the use of renewable resources

- to support development of effective private sector standards by transferring DOE research

to work with states, the buildings community, and code development organizations to ensure the development and implementation of successful building standards. 
A key component to meeting the goals and objectives of the BESP is the on-going development and maintenance of computer software. The Software Development and Support Project provides the necessary support for all of the analytical tools and designs used on the BESP.

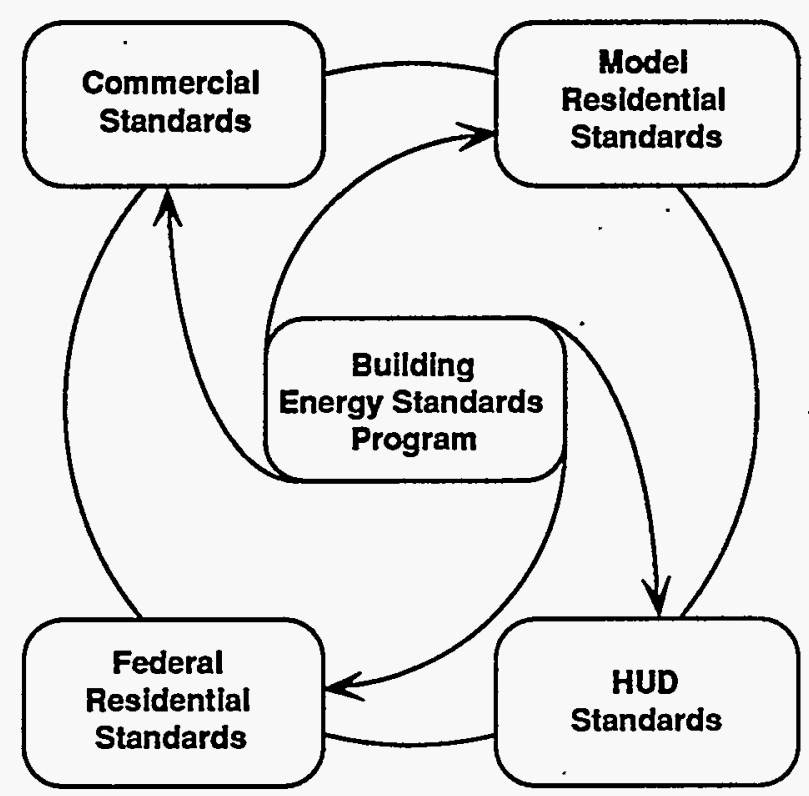

PNL is helping DOE develop and implement energy conservation standards for new residential and commercial bulldings. Before the full benefits of the standards can be realized, states must adopt them; architects must incorporate them into building designs; and code officials must enforce them.

\section{Commercial Standards}

The Commercial Standards Project focuses on developing and implementing energyefficiency standards for new commercial and multifamily high-rise buildings. Project staff provided technical support to assist both DOE and ASHRAE in their respective standardsdevelopment activities (10 CFR 435, Subpart A, Energy Conservation Voluntary Performance Standards for New Commercial and Multi-family High Rise Residential Buildings; Mandatory for Federal Buildings; Interim
Rule and ASHRAE/IES Standard 90.1-1989, Energy-Efficient Design of New Buildings Except Low-Rise Residential Bulldings).

During FY91, the energy and economic impacts of the energy standards for commercial buildings were assessed. This assessment formed the basis for a report to Congress. In another study, the training needs of building code officials, architects, and engineers were assessed.

\section{Residential Standards}

The work on residential standards focuses on developing and implementing energyefficiency standards for new residential buildings, including low-rise multifamily buildings. During FY91, the initial draft of DOE's interim model residential energy standard for nonfederal residential buildings was completed. During FY92, PNL will assist $\mathrm{DOE}$ in issuing the standard, which provides energy-conservation guidelines for privately owned buildings. Compliance with the standard is voluntary.

During FY91, efforts on the Interim Energy Conservation Standards for New Federal Residential Buildings focused on evaluating and demonstrating the interim standards for federally owned residential buildings, such as military housing. Activities included assessing the standards' impact on federal agencies, designers, builders, costs, and energy use. During FY92, the findings and recommendations from the demonstration will be addressed.

For more information on the Building Energy Standards Program, contact

Ronald E. Jarnagin 509/375-3813 


\section{Federal Energy} Management Program

The Office of Federal Energy Management Program (FEMP) within OBT is charged with improving the energy efficiency of the federal government. FEMP's mission is twofold: 1) to improve the efficiency and fuel flexibility of energy use in federal buildings, transportation, and operations and 2) to facilitate the transfer of energy management experience within the federal sector. To accomplish this mission, FEMP relies largely on PNL as its lead laboratory for federal energy management.

PNL provides direct technical and management assistance to federal agencies and installations. To provide this assistance, PNL has developed tools such as methods and models for analyzing energy issues, procedures for testing the energy performance of equipment and systems, and Integrated approaches to planning and acquiring energy resources.

\section{Federal Energy Decision Screening System}

The Federal Energy Decision Screening (FEDS) System is a top-down, systematic approach for addressing all energy issues at large federal installations. PNL has developed this system, which is designed around a family of tools that provide a comprehensive approach to fuel-neutral energy resource planning and acquisition. These tools include analysis and decision software developed specifically for FEDS, existing standalone software, procedures, algorithms, data collection protocols and specifications, and databases. In addition to developing the system, PNL also will train staff who help energy managers plan and acquire energy resources.

Intended for use in federal agencies and at federal installations, FEDS accommodates the special energy problems of those agencies and installations. For example, many of the facilities are older and are not energyefflcient. In addition, onsite energy expertise, energy-use information, and energy metering capabilities are minimal.

During FY91, FEDS staff developed two toplevel analysis tools for federal energy managers: FEDS Level-1 and a lighting technology screening matrix.

FEDS Level-1 is a menu-driven software program that provides a preliminary review of the energy situation at an installation or facility. Such a review enables staff to identify and characterize cost-effective energy projects; to identify the likely enduse targets for those projects; and to estimate the energy savings, energy cost savings, and investment requirements. At this level, only minimum input data are required, with the analysis depending largely upon built-in assumptions.

The lighting technology screening matrix will be an important tool for the Federal Relighting Initiative.

\section{Federal Relighting Initiative}

PNL is helping develop a comprehensive process for cost-effective relighting of federal facilities. This process includes the development of

a lighting characterization tool for identifying relighting opportunities 
- the lighting technology screening matrix tool for identifying appropriate relighting technologies

- generic guidelines and documentation for soliciting shared energy savings relighting projects

- procedures for evaluating/verifying relighting projects.

As part of this activity, an assessment was begun to ascertain the federal relighting potential. The assessment will be completed during FY92.

At the current stage of development, the lighting technology screening matrix gives cost and performance data for approximately 200 fluorescent fixture variations, 70 incandescent variations, and 100 high-intensity discharge variations.

The screening matrix incorporates capital costs, operation and maintenance costs, energy costs, lumen equivalent, annualized total costs, life-cycle costs, annual energy savings, levelized cost of the energy saved. and the net present value of a retrofit project for all feasible improvements to existing lighting technologies. The development of this and other appropriate tools is being coordinated with a federal relighting expert system being developed by the National Renewable Energy Laboratory in Golden, Colorado.

Draft specifications for efficient lighting technologies-lamps, fixtures, ballasts, and controls-were developed to provide generic guidelines for federal procurements. These specifications, which are based on state-ofthe-art lighting systems, will be incorporated into the Defense Logistics Agency's catalog to help purchasers select lighting technologies based on life-cycle costs. Manufacturers were consulted to ensure that products are available from at least three sources.

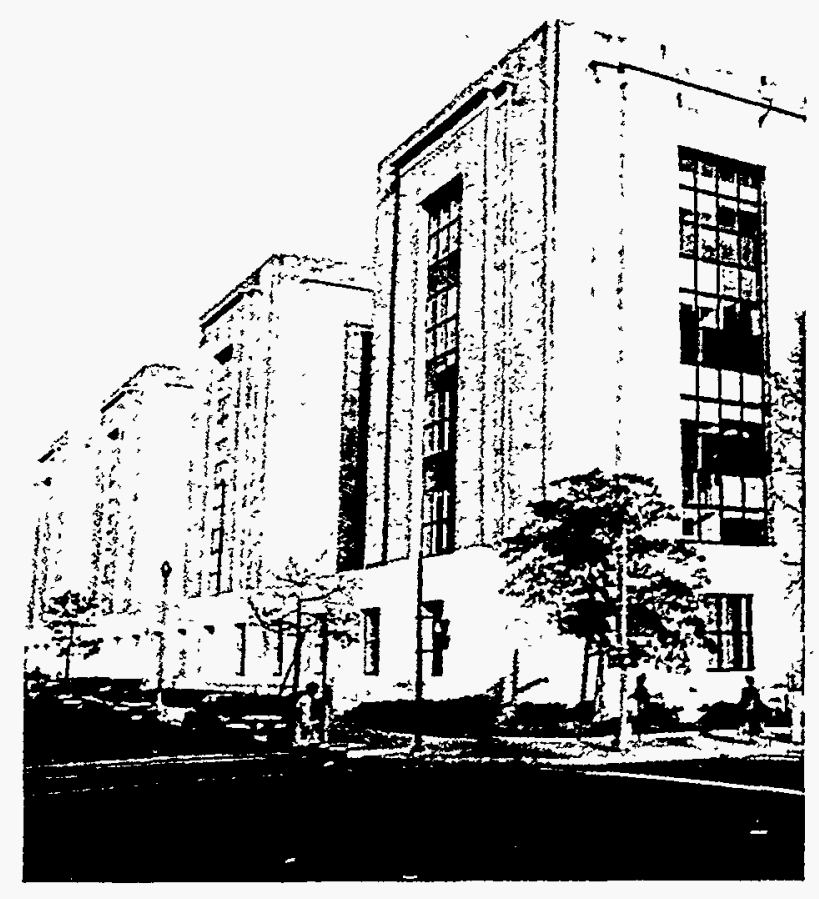

In cooperation with the Potomac Electric Power Company (PEPCO), FEMP and PNL are particlpating in the relighting and evaluation of a portion of the Mary Switzer Building in Washington, D.C. (PEPCO provides electricity to the building.) Relighting of this building will be completed in FY92, with an evaluation to follow.

\section{Testbeds}

FEMP is targeting certain federal sites as testbeds, i.e., locations at which the reliability and cost-effectiveness of advanced energy technologies will be demonstrated through actual use. The intent of these testbeds is to accelerate widespread adoption of the demonstrated technologies within the federal sector and to stimulate commercialization of U.S.-developed technologies.

A testbed demonstration is implemented through a CRADA and provides for the cost of the demonstration to be shared by FEMP, a federal site, an equipment manufacturer. 
and a servicing utility. PNL initiated two testbed development activities in FY91 and has received good responses from the federal government and industry on the testbeds program.

The two testbed activities focused on new high-efficiency HVAC equipment. One is a small tonnage ( $<25$ ton) unitary rooftop HVAC system that uses natural gas to fuel both the heating and cooling cycles. The other is a large tonnage ( $>75$ ton) gas-enginedriven chiller.

In FY92, these testbeds will be implemented and a solicitation will be initiated for additional technologies that are candidates for a testbed.

\section{Mobile Energy Laboratory Testing}

The Mobile Energy Laboratory (MEL) is a fully equipped, state-of-the-art system for metering and analyzing energy use. These mobile laboratories contain the equipment and analysis tools necessary to monitor energy end-use consumption and equipment performance and to evaluate a full range of strategies for reducing energy cost.

The primary objectives of the MEL program are 1) to advance the state of energy-monitoring technologies through comprehensive field testing and analysis; 2) to demonstrate and apply the technology; 3) to enhance the cost-effectiveness of each technology; and 4) to transfer the technology to the client and/or private sector for routine application.

PNL operates these mobile laboratories, which are deployed for energy studies at federal installations across the continental United States.
In FY91, MEL evaluations were conducted on building energy usage and lighting.control systems; steam distribution systems; sewage pump stations; boilers; chillers; and electrical transmission and distribution systems for the U.S. Army, DOE, and the Department of Transportation.

For more information on the Federal Energy Management Program, contact

\section{J. William Currie} 509/375-3969

\section{Economics and Systems Analysis Program.}

The objective of the Economics and Systems Analysis Program (ESAP) is to provide OBT with analytical and informational support to enhance its program planning. The emphasis of the program changes somewhat from year to year to reflect the dynamic environment in which OBT operates. For example, during FY90, the main analytical concern for OBT was providing input to the National Energy Strategy (NES). As a consequence, ESAP . resources were largely devoted to assisting OBT in providing data and performing analyses in support of the NES.

In contrast, during FY91, program resources were devoted to the following activities:

estimating the technically achievable energy savings potentials (near-, mid-, and long-term) for OBT R\&D program elements

developing new estimates of the nation's aggregate commercial floorspace, with selective regional breakouts by building type 
providing input to the DOE Energy Information Administration working group on the next Commercial Building Energy Consumption Survey, to try to improve the usefulness of the survey data from OBTs perspective.

During FY92, ESAP will conduct the analyses OBT requires to improve the analytical foundation of its program planning. As part of this effort, PNL will refine its Commercial Sector Energy Model through development of prototypical buildings and regional estimates of commercial floorspace.

For more information on the

Economics and Systems Analysis

Program, contact

Andrew K. Nicholls

202/646-5238 technology developments in Japan to a DOE study on desiccant R\&D in the United States.

Involvement in the areas of CFCs and desiccants is expected to continue during FY92. The BETA staff will investigate the Third Generation Alternative Refrigerants Initiative, which Japan has undertaken to develop alternatives to CFCs. Staff also will provide additional expertise in desiccants technology, ultimately helping to establish a DOE program plan in this area.

For more information on the Buildings Equipment Technology Assessment Program, contact

Bruce. R. Kinzey 202/646-523I

\section{Buildings Equipment Technology Assessment Program}

The Buildings Equipment Technology Assessment (BETA) Program provides engineering and economic analysis to OBT's Buildings Equipment Division. During FY91, the BETA Program assisted in a technical reassessment of the Montreal Protocol (an international agreement to eliminate the use of chlorofluorocarbons [CFCs], which are partially responsible for the depletion of the stratospheric ozone layer). In addition, BETA staff contributed information on desiccant

\section{Support to Pacific Gas and Electric Company's $\mathrm{ACT}^{2}$ Project}

The Research and Development Department of the Pacific Gas and Electric Company (PG\&E) began the Advanced Customer Technology Test for Maximum Energy Efficiency (ACT $\mathrm{T}^{2}$ for Maximum Energy Efficiency) project in 1990. The program was begun to test the hypothesis that "substantial energy savings (perhaps as high as $\mathbf{7 5 \%}$ over current practice) can be achieved in buildings, or industrial and agricultural processes, at economic costs through the use of new energy-efficient end-use technologies and systems." 
The DOE is assisting PG\&E with the $\mathrm{ACT}^{2}$ project by providing a PNL staff member to work directly with the $\mathrm{ACT}^{2}$ team. As a member of the $\mathrm{ACT}^{2}$ team, the PNL staff member is providing general technical assistance for the project, including energy-efficient bullding design, building commissioning, energy simulation, building energy economics and life-cycle costing. bullding system integration, and measurement and evaluation of energy-efficiency demonstrations.
For more information on DOE's involvement in the $\mathrm{ACT}^{2}$ project, contact

Drury B. Crawley

509/375-6367 


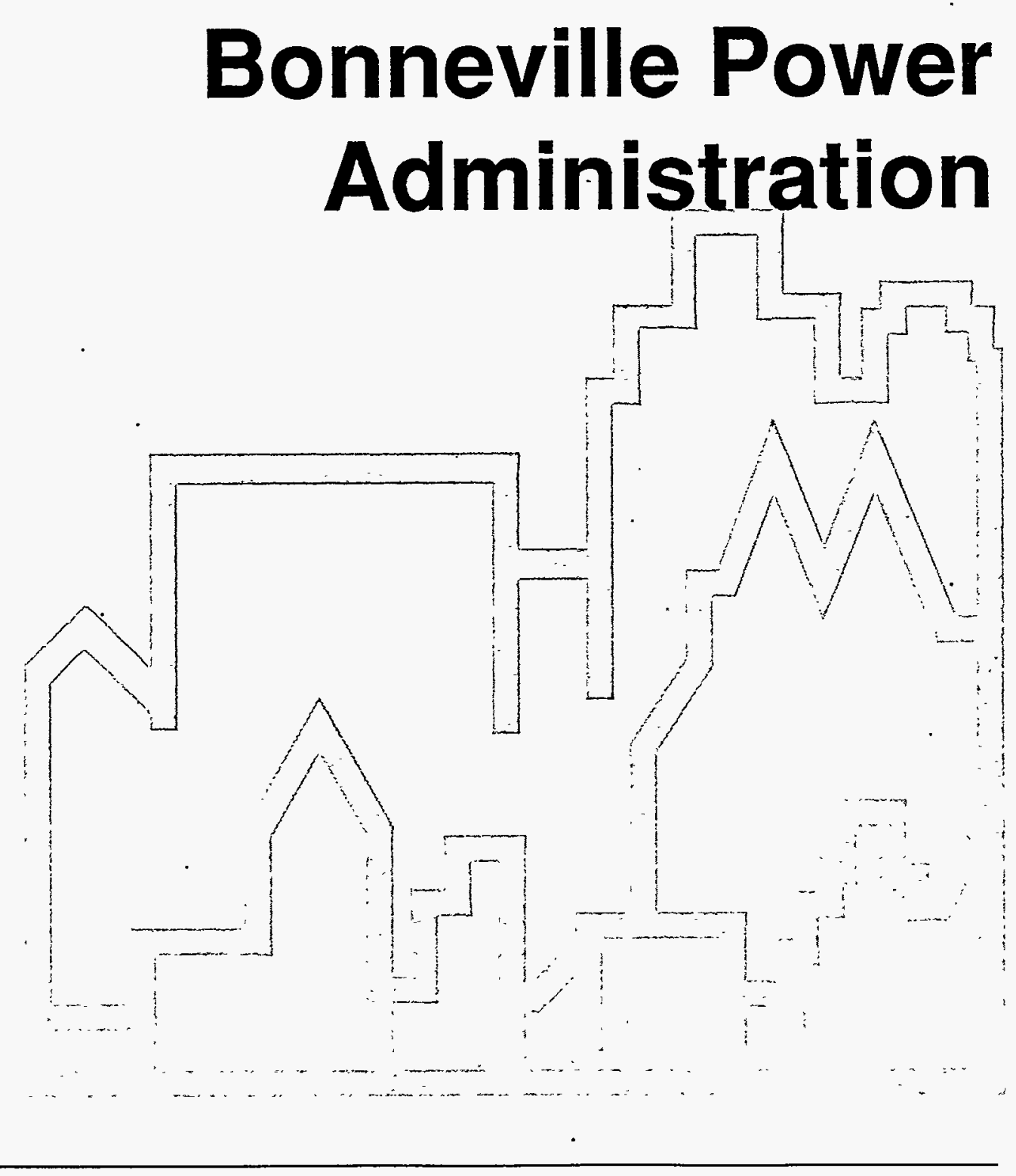




\section{Bonneville Power Administration}

The Bonneville Power Administration (Bonneville) markets power to approximately 120 retail electric utilities and several large industrial and federal customers. In so doing. Bonneville provides approximately half the electricity used in the Pacific Northwest. As a result, Bonneville plays a central role in the region's planning for and transmission of electric energy. Bonneville's strategy is to provide for future energy needs through a combination of conservation and new generating facilities.
Bonneville programs are coordinated through PNL's office in Portland, Oregon. The primary focus of that support is assessment, planning, and evaluation to support acquisition of energy resources. PNL staff assess the conservation potential of new end-use technologies, building codes, and construction practices; design new conservation programs; and evaluate the energy resulting from resource acquisition programs.

\section{Regional End-Use Metering Program}

Since 1983, Bonneville has conducted metering programs to obtain information on the end uses of energy. Bonneville uses this information as it forecasts demand, plans conservation programs, and evaluates the performance of technologies and programs.

During FY91, the metering software was improved to make the delivery and processing of data more efficient and to reduce operational costs. These improvements included modifying data loggers to improve their performance, creating 6-month data files to reduce data processing time. and transmitting data in compressed 
formats to reduce the data delivery time. As a result of these improvements, data can now be transmitted, recovered, and analyzed much more quickly. These improvements result in an annual savings of approximately $\$ 75,000$.

Activities during FY92 will focus on developing a flexible data pipeline that can acquire and process data for a variety of metering programs. The completed pipeline will be able to communicate with a variety of data loggers; produce routine data summaries, as desired: and store data in a variety of structures.

For more information on the Regional End-Use Metering Program, contact

William F. Sandusky

509/375-3709

\section{Manufactured Housing Technical Transfer Project}

The Manufactured.Housing Technical Transfer Project is a multiyear program that addresses energy efficiency in manufactured housing. Through this program, Bonneville hopes to gain a better understanding of and working relationship with the manufactured home industry. Two initial marketing studies showed a market for energy-efficient manufactured homes. One of these studies also showed how Bonneville could use its existing Super Good Cents Program to promote energy-efficient manufactured homes.
To pursue these opportunities, PNL has assisted Bonneville with a series of demonstration projects. In the first, five energyefficient manufactured homes were built and monitored for 3 months to determine their energy consumption. The data collected indicate that these homes used $4 \mathrm{kWh} / \mathrm{ft}^{2}-\mathrm{yr}$ for space heating, while comparable manufactured homes that do not include energyefficient features used over three times more (13.8 kWh/ $\mathrm{ft}^{2}$-yr).

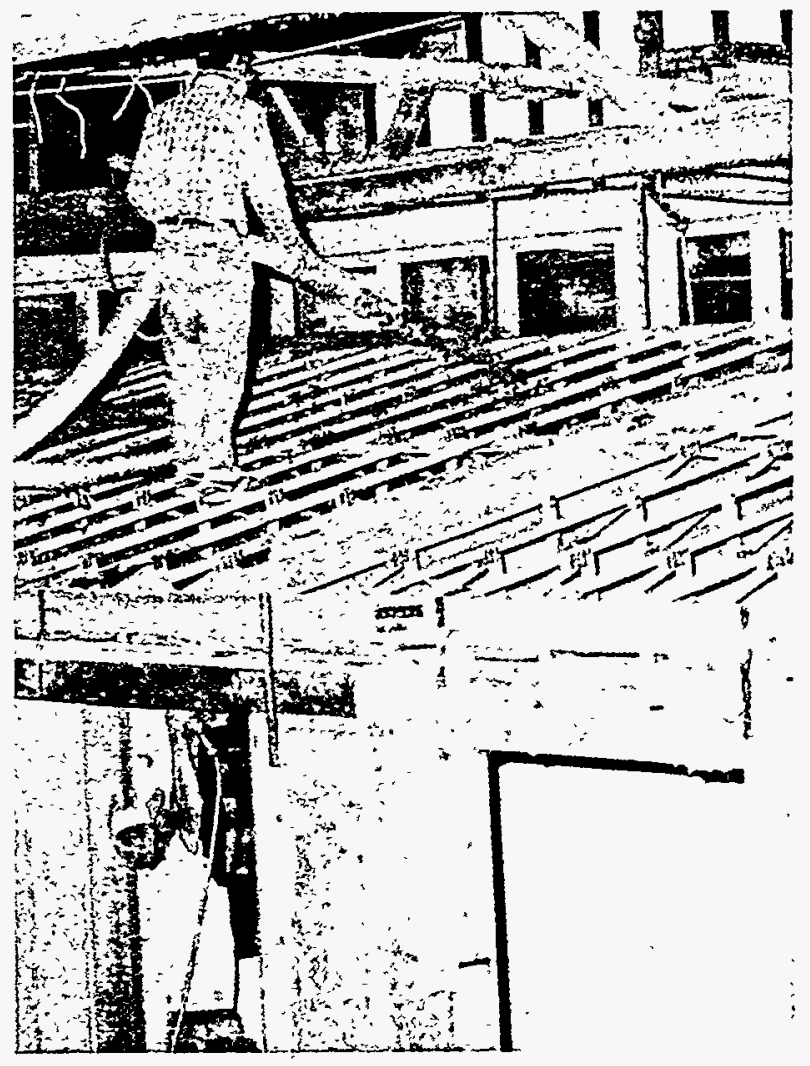

Approximately 35\% of all new electrically heated homes in the Pacific Northwest are manufactured homes. These homes use approximately $25 \%$ more energy per square foot than site-built homes. PNL is assisting Bonneville in its efforts to reduce that percentage by improving energy efficiency in manufactured homes. 
Recently, PNL helped Bonneville conduct and analyze results from another demonstration project, the Residential Construction Demonstration Project (RCDP). In this project, eight manufacturers built 150 manufactured homes to the Model Conservation Standard (MCS) for residential energy efficiency. Manufacturers who took part discovered that producing the homes required almost no changes in their standard production processes, even though working to the MCS meant installing innovative energy-efficiency upgrades such as low-E glazing, vinyl frame windows. The RCDP results were used to establish requirements for including manufactured homes in Bonneville's Super Good Cents Program.

PNL is currently assisting Bonneville in an effort to exchange information on energyefficient manufactured homes with other parties throughout the United States.

\section{For more information on the Manufactured Housing Technical Transfer Project, contact}

Allen D. Lee

503/230-7584

\section{Residential Fuel Choice Project}

Bonneville has recently instituted several projects to promote the residential MCS. One such project, the Residential Fuel Choice Project, investigated interactions between the MCS and fuel choice in the Pacific Northwest. The specific goal of the analysis was to develop models of consumer choice that could help predict the impacts Bonneville programs have on fuel choice.

During FY91, the relationships among Bonneville projects, residential fuel choice, and consumer acceptance of energy-efficient residential construction were investigated through several research activities: surveys, econometric modeling, and conjoint analysis. Researchers surveyed residential homeowners in the region to determine their attitudes and concerns about energy efficiency and fuel choice.

Two key findings of the survey were that fuel choice is determined primarily by price and that natural gas has become the preferred fuel in the Northwest. A price and demand model developed for the project showed that buyers are willing to pay for energy efficiency. Specifically, they are willing to pay approximately $\$ 4$ more per square foot for a home built to the residential MCS.

Other findings include the following:

1) electricity is the dominant space-heating fuel in the Northwest, but natural gas is commanding an increasing share of the market; 2) builders select a heating fuel primarily in response to direct buyer requests (for custom-built homes) or indirectly through market demand; and 3) both rebates and utility rate reductions can be used to increase the market share of homes with specific heating fuel types.

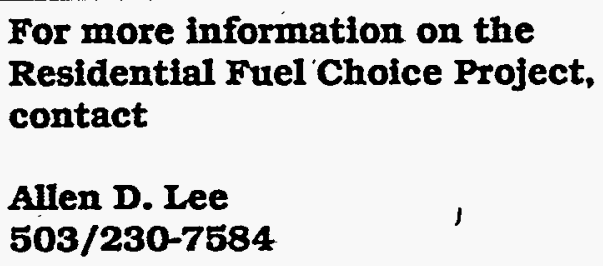




\section{Evaluation Research Assistance Project}

In support of its planning and acquisition efforts for energy-efficiency programs, Bonneville conducts evaluations to monitor the efficacy of these programs. Bonneville relles upon PNL to support evaluations of a spectrum of energy-efficiency measures and practices.

The largest evaluation activity undertaken during FY91 was a data collection program designed to identify potential energy savings from the retrofit of energy-efficient showerheads. This information will be used to develop an energy savings verification scheme that Bonneville will use to reimburse customers for showerhead savings. Initial field data indicated that energy-efficient showerheads in the region typically flow at a rate of about 3.5 gallons per minute. This contrasts with the 5 to 6 gallons per minute flow rate for non-energy-efficient showerheads.

-Another major activity was to conduct an early evaluation of a program in Washington State to educate home builders, code enforcement officials, and others about the state's new energy-efficiency building codes.

For more information on the Evaluation Research Assistance Project, contact

W. Michael Warwick $503 / 230-4650$

\section{Energy Edge Program}

The goal of the Energy Edge Program is to demonstrate that new commercial buildings can be built to use no more than $70 \%$ of the energy specified by the MCS. Through a design competition, 28 bulldings of various sizes and types were selected to participate in the program. Bonneville paid incentives for the incremental costs of designing and installing a variety of energy conservation measures in the buildings.

Detailed hourly energy-use data being collected from each building will be used to calibrate DOE-2 models of the buildings. A hypothetical base-case model for each building will then be derived from the calibrated models. Ultimately, the models will be used to evaluate the cost-effectiveness of the installed energy conservation measures.

During FY91, PNL was responsible for processing the hourly data, checking its quality, and archiving it in a format that Bonneville's analysis contractors could use. Data processing will continue through FY92, with the entire data set being transmitted to Bonneville no later than March 31, 1993, for installation on its computer system.

For more information on the Energy Edge Program, contact.

William F. Sandusky 509/375-3709 


\section{Tacoma Multifamily End-Use Monitoring Project}

Begun late in FY89, this project was designed to provide information to three groups in the Paciflc Northwest: Bonneville, the Northwest Power Planning Council (NWPPC), and Tacoma Public Utilities (TPU).

To improve its ability to forecast and evaluate demand for power, Bonneville wanted to know how much energy existing and MCS multifamily units use for heating and hot water. The NWPPC wanted similar information to improve its confidence in its energy forecasts. Further, TPU wanted to show real estate developers, tenants, and elected representatives the effectiveness of the multifamily MCS in reducing energy consumption.

A monitoring program was established for 10 multifamily buildings that would be constructed within or near the TPU service area. Half of the bulldings would be constructed to the MCS, while the others would be constructed to current standards. The energy use of the two building types would then be compared.

Metering equipment was installed, and data collection from all of the sites began in March 1991. The end uses being metered are total usage, hot water, space heat, and "other." Inside air temperatures are being collected in each unit, and outside air temperatures are being collected for each complex.

For more information on the Tacoma Multifamily End-Use Monitoring

Project, contact

William F. Sandusky 609/375-3709

\section{Equivalent Thermal Parameters Project}

The Equivalent Thermal Parameters (ETP) Project began in FY91. The objective is . to develop and test an empirically based approach to thermal analysis of commercial buildings.

\section{The ETP modeling process}

- can be easily calibrated to hourly enduse metered time-series data

- can use hourly streams of input data

- is computationally efficient

- reflects real building operations and use

- provides parameters that allow the user to gauge the performance of systems such as HVAC and envelope

accurately describes hourly HVAC loads

- accurately predicts the effects of modifications to building structure and equipment efficiencies.

The model's descriptive capabilities are being developed and tested using pseudodata generated by a series of DOE-2 simulations. Models of approximately 30 office and retail buildings will then be constructed from metered end-use data.

For more information on the Equivalent Thermal Parameters Project, contact

Robert G. Pratt 509/375-3648 


\section{Resource Supply Expansion Program}

The 1980 s found Bonneville with a comprehensive plan for meeting growing loads and an aggressive program for demand-side management. At that time, Bonneville had a surplus of generating resources. Recent growth, however, has exhausted this surplus, and projections indicate that significant amounts of new resources will be needed.

The demand for power could exceed the currently identified resource available through conservation. In such a case, Bonneville would have to rely primarily on electricity generated through conventional means (e.g., hydro) and on renewable generation technologies, many of which have uncertainties regarding performance and reliability. Bonneville seeks to increase its resource planning options by further demonstrating renewable resources and potential new sources of energy efficiency.

A critical ingredient in any new resource development in the Pacific Northwest is utility participation. Bonneville provides power to retail utilities that serve approximately half of the region's consumers. Bonneville expects these utilities to assist in meeting future loads by encouraging energy efficiency among their customers, encouraging the development of potential renewable resource sites in the utility service area, and developing conventional generation resources (e.g., cogeneration and/or small hydro).
In partnership with these utilities, other utilities in the region, the NWPPC, DOE, and other organizations, Bonneville is trying to identify potential new resources, both from renewables and from conservation (energy efficiency), and to implement appropriate demonistration projects to confirm these resources and their economic potential.

This effort, called the Resource Supply Expansion Program (RSEP), is expected to be a 10-year collaborative effort to identify and document renewable and energyefficiency resources that have significant potential for the 1995 to 2005 period. Resources confirmed through RSEP will be incorporated into Bonneville's resource supply curves and future resource acquisition efforts.

Early efforts under RSEP have included developing a process for bringing the energy interests of the region together to design and implement the resource $R \& D$ collaboration. The renewable resource potential of given sectors and geographic areas of the region and the technologies that are available for demonstration have been reviewed.

For more information on the Resource Supply Expansion Program, contact

W. Michael Warwick $503 / 230-4650$ 


\section{Other Federal}

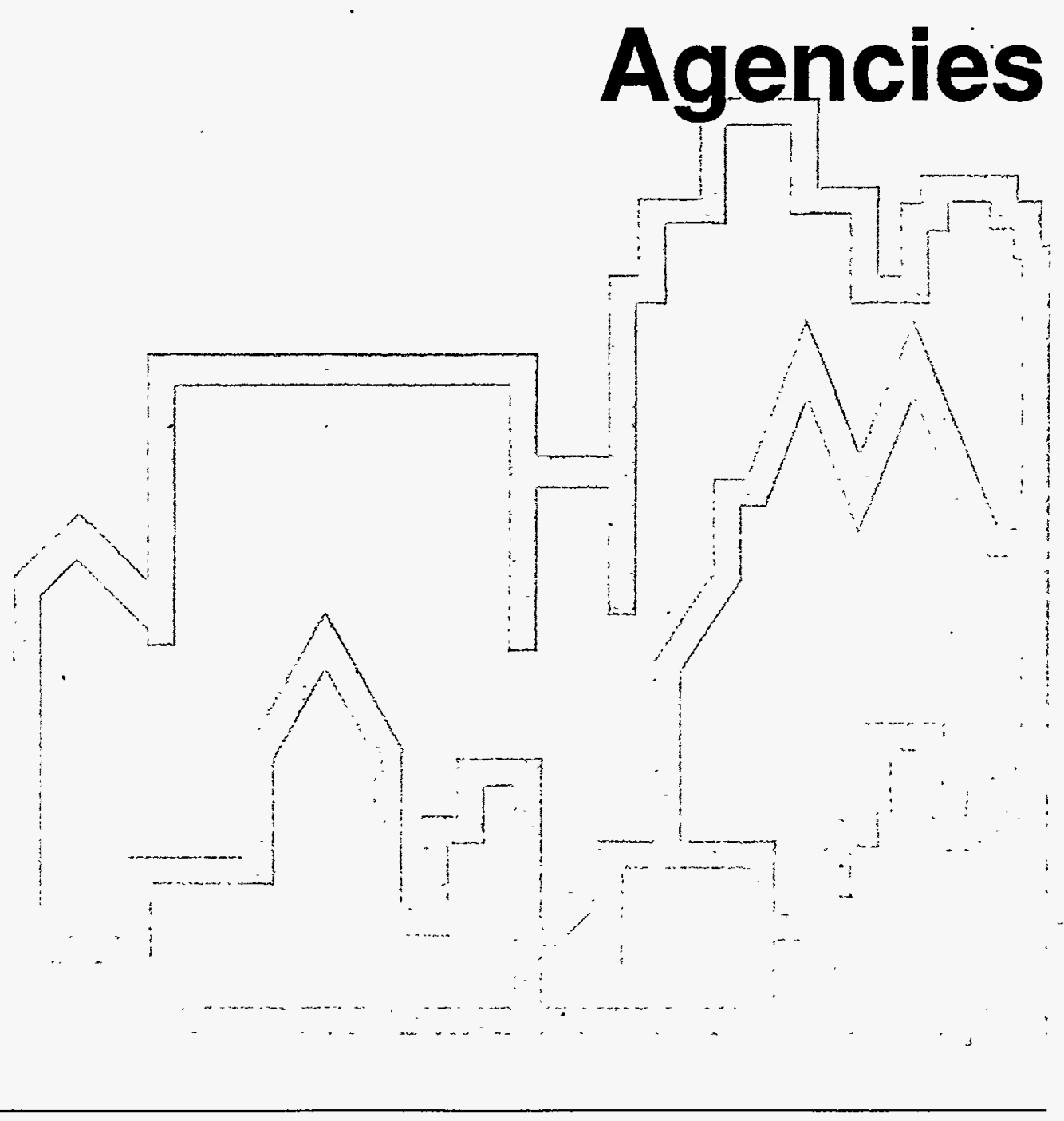





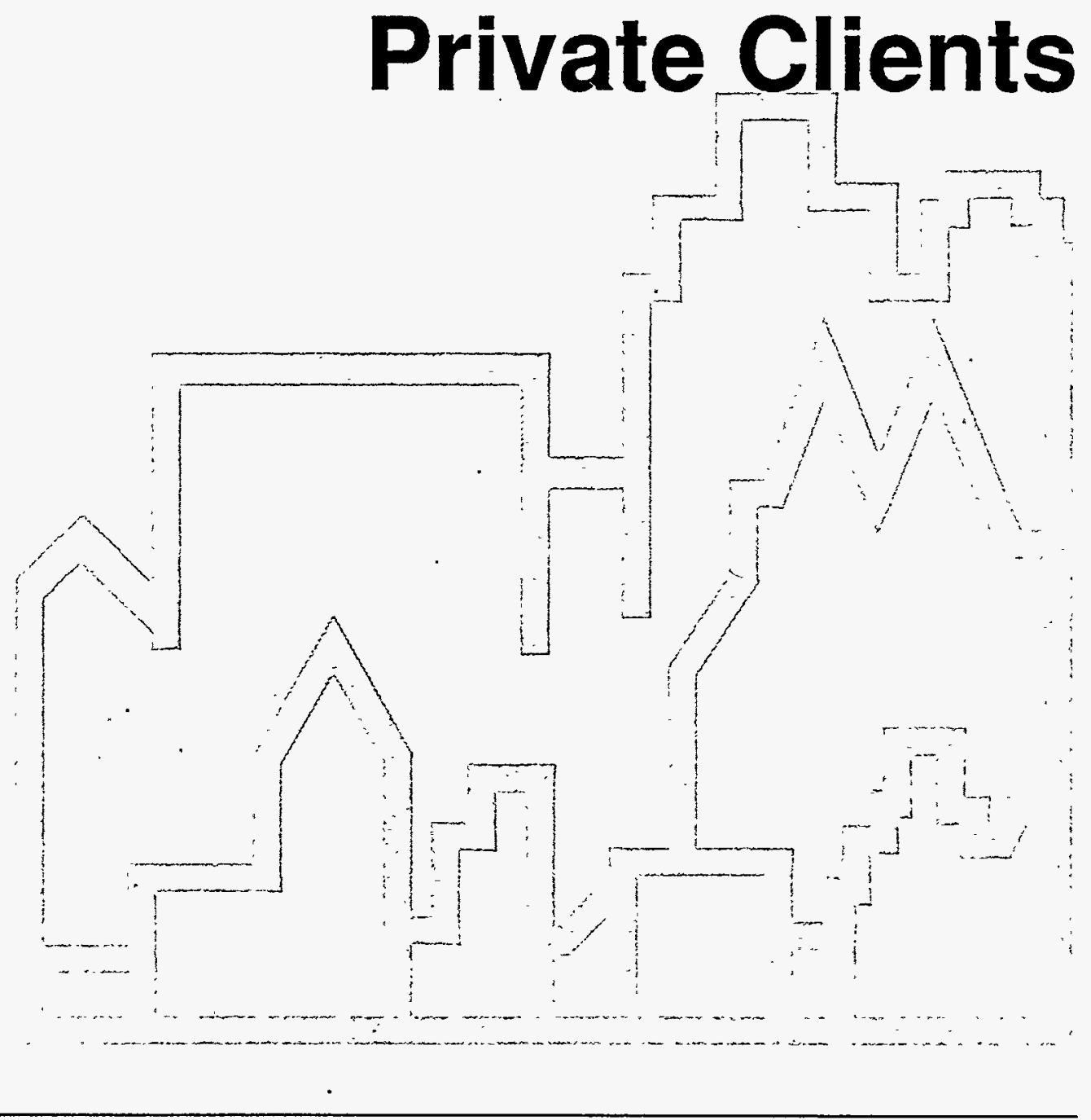





\section{Private Clients}

Programs and projects for private (nonfederal) clients directly support activities conducted for DOE and provide a key linkage to organizations in the private sector. Work for private clients typically focuses on a specific requirement, and the term of the contract is usually shorter than those for the federal government.

In FY91, Battelle staff conducted projects for six private clients: the Gas Research Institute; the Pennsylvania Power \& Light Company; the Pacific Gas and Electric Company; the National Research Council, Canada; the Northwest Power Planning Council; and the Mineral Insulation Manufacturers Association.

\section{Gas Research Institute}

In 1986, the Gas Research Institute (GRI) began a project to characterize the energy requirements of the existing office building stock in the United States. Between 1986 and 1990 , Battelle created a database of energy and physical characteristics and developed 20 categories to describe the office building stock.

During 1991, DOE-2 input files were created for those 20 categories, as well as for an additional 10 (to represent recent and future office buildings). The resulting loads data (heating, cooling, and other) were derived for use by GRI and its subcontractors in technology assessments and R\&D planning. Battelle staff also analyzed the two new ASHRAE standards (90.1-1989 and 62-1989), assessed the market for floor-byfloor HVAC equipment, and compared the energy and economics of central versus distributed HVAC systems.
As part of the work to evaluate central versus distributed HVAC systems, Battelle commissioned modifications to the DOE-2 program to allow it to handle vertical . package cooling units. Lawrence Berkeley Laboratory has incorporated these modifications into the newest version, DOE-2.1E.

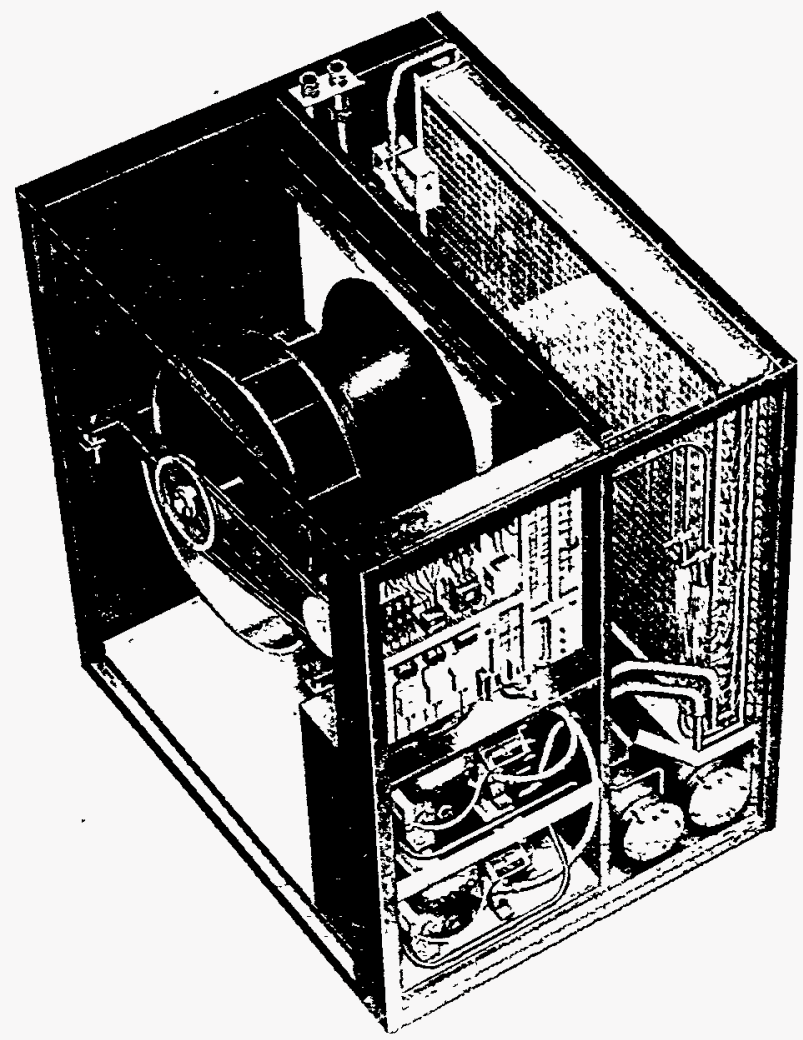

As a result of Battelle's energy-use and market assessment of electric floor-by-floor HVAC systems, the Gas Research Institute will explore the potential for a similar gas system.

For more information on work for the Gas Research Institute, contact

Drury B. Crawley

509/375-6367 


\section{Pennsylvania Power \& Light Company}

Pennsylvania Power \& Light Company (PP\&L) of Allentown, Pennsylvania, sponsored the design and construction of five passive solar homes as part of the Passive Solar Research Project. This project was designed to demonstrate the energy and peak load savings from passive solar features in the homes.

The solar space-heating features included a mixture of direct gain. Trombe wall, and sunspaces integrated into fairly traditional architectural designs that also incorporate very high levels of insulation. Thermosyphon water-heating systems were also incorporated.

Metered energy-use data were collected for 2 years, and the space- and water-heating performance of the passive solar features was analyzed. The analysis showed the following:

The energy savings provided by the passive solar space-heating features were in the range of $15 \%$ to $40 \%$ of the annual heating requirements.

- The impact of the solar features on PP\&L's 9 a.m. and 10 a.m. winter peak loads was minimal.

- The solar water-heating system appeared to be very cost-effective and entirely eliminated summer water-heating loads.

Battelle used the analysis results to develop conclusions about the general efficacy of passive solar energy for a utility in a climate such as Pennsylvania's. Battelle also provided PP\&L with guidance on the effectiveness of specific solar features. This project was completed during FY91.

\section{For more information on work for} PP\&L, contact.

Robert G. Pratt 509/375-3648

\section{Pacific Gas and Electric Company}

Since 1988, Battelle has been conducting the Commercial End-Use Metering Project for Pacific Gas and Electric Company (PG\&E) in San Francisco. The goal of this project is to provide data that will enable PG\&E to characterize its commercial market by end use. This characterization will ultimately provide PG\&E with the ability to establish reliable estimates of end-use loads for important commercial customer markets.

Forty-seven buildings in three of PG\&E's six service areas were selected for metering. Included in the 47 were office and retail buildings, restaurants, warehouses, and grocery stores. Lights, HVAC systems, external loads, and "other" end uses were metered in all buildings; food preparation, refrigeration, and data processing were also metered in some of the buildings. Activities during FY91 focused on collecting and processing the data, then transferring it to PG\&E. 
Through another of PG\&E's projects, the Advanced Customer Technology Test for Maximum Energy Efficiency Project, metering equipment was also installed in an office bullding. That building will serve as a demonstration site for testing promising end-use energy-efflciency technologies. Battelle's metering activities will be completed by June 30, 1992, after which, the metering program will be turned over to PG\&E.

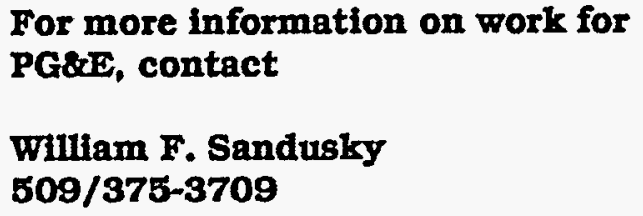

\section{National Research Council, Canada}

Battelle evaluated ASHRAE/IES Standard 90.1-1989 and provided recommendations for adapting it to create a new commercial building energy code for Canada. The National Research Council, Canada, requested that particular emphasis be placed on the building envelope requirements that would be applicable and reasonable for Canada's climate and economic conditions.

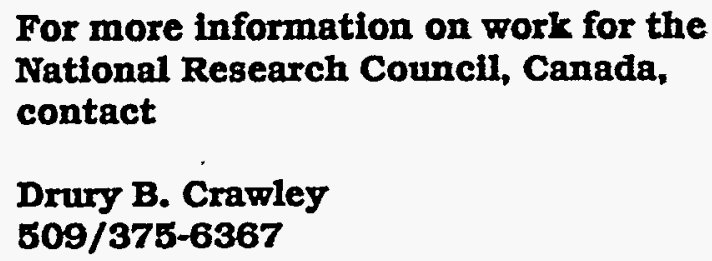

\section{Northwest Power Planning Council}

The analysis of metered end-use data provides insight that can have bearing on resource planning issues confronting the Pacific Northwest. Battelle's support for NWPPC planning has focused on three specific areas:

- improving the accuracy of energyefficiency supply curves by resolving large differences between metered heating and cooling loads and those predicted using DOE-2 prototypes of the region's commercial and retail buildings

- providing specific input on heat losses from residential hot water tanks, on associated efficiency measures, and on hot water use by households with various numbers of occupants of various ages

- suggesting modifications and/or improvements to the commercial sector resource planning and forecasting process in light of the availability of, and key findings from, metered data and a new commercial building survey.

Work in FY90 resolved many of the discrepancies in the heating and cooling loads in commercial buildings. Evidence gathered during FY91 suggests that a substantial portion of the remaining error (i.e., predictions of cooling loads are low) is explained by the fact that the prototypical DOE-2 buildings are much too massive.compared with typical construction. 
Also during FY91, residential water-heating data were revised and improved. These data provide empirical estimates of heat losses from the existing population of water tanks, as well as the impact of insulating wraps and bottom boards, pipe insulation, and anticonvection valves. The analysis showed that households have a base use regardless of the number of occupants and that consumption above the base is strongly related to the age of the occupants (small children and the elderly use much less hot water than other occupants).

A review of the commercial sector planning process conducted in FY91 will be summarized during FY92 and recommendations made for improving the process and its input data.

For more information on work for the Northwest Power Planning Council, contact

Robert G. Pratt 509/375-3648

\section{Mineral Insulation Manufacturers Association*}

In 1990, the Mineral Insulation Manufacturers Association (MIMA) initiated a study with Battelle to compare the economic effects of three residential energy conservation building standards. Battelle analyzed the Model
Energy Code (MEC) 1986 and the MEC 1989, both from the Council of American Building Officials, and the Minimum Property Standards from HUD. The study was completed early in 1991 with the release of a comprehensive report.

Battelle used a computer program developed for DOE to perform the analyses. The economic effects of the standards were presented using three different buyer economic criteria: life-cycle cost, first-year cash flow, and simple payback. The impacts were analyzed in 17 different locations.

From a life-cycle cost perspective, Battelle found that the MEC 1989 saved buyers money relative to the other two standards. Compared with the other standards, the MEC 1989 also produced a positive cash flow to buyers in the first year.

The report recommended that standards take regional climate and fuel price difference into account and also incorporate future costs and benefits.

MIMA issued a conventional press release and a video press release based on the report.

\section{For more information on work for the} Mineral Insulation Manufacturers Association, contact

Allen D. Lee $503 / 230-7584$

\footnotetext{
- In January 1992, MIMA became the Northwest American Insulation Manufacturers Association (NAIMA).
} 


\section{Technology Deployment}

University Relations

Energy Technology Development Initiative 



\section{Technology Deployment}

\begin{abstract}
A key goal of PNL's Buildings Energy Program is to deploy energy-efficient technologies to help decision makers-the NWPPC, federal agencies, utilities, architects, builders, users-make more informed decisions about energy use.
\end{abstract}

Successful technology deployment depends on continuous awareness of the needs of Individuals and organizations directly or indirectly involved with the buildings sector. These groups include manufacturers, utilities, trade associations, community organizations, professional societies, universities, and state and local governments.

Staff in the Buildings Energy Program used several methods in FY91 to develop and maintain this awareness:

presented research findings at nationally recognized conferences

worked directly with trade and professional organizations

- provided technical assistance to builders, end-users, utilities, and others

a. published research findings in technical and trade journals

- developed computer-based informationmanagement tools

- engaged in cooperative research with universities

- entered into CRADAs with the private sector.
Although each mechanism is important, the CRADA deserves particular mention. CRADAs are agreements between DOEfunded laboratories and the private sector. They offer several advantages to privatesector research partners: exclusive licensing of DOE inventions, protection of related technical data for up to 5 years, and relatively quick paperwork and processing.

During 1991, PNL signed a CRADA with the city of Richland (Washington) to monitor the effectiveness of a new, energy-efficient electric heat pump and the total housing energy consumption in 35 Richland residences. The city hopes the data will confirm estimates of energy saved through the use of the heat pump and will provide a clear profile of energy use in Richland homes. The study results will be applied to plan future utility conservation and marketing programs.

Staff in PNL's Buildings Energy Program have received wide recognition for their technology transfer efforts. The commercialization of the energy data logger is one excellent example. In the early 1980s, with OBT providing the seed money, researchers at PNL created and tested a prototype energy data logger. The data logger was field-tested through Bonneville's ELCAP, then licensed to Synergistic Control Systems in 1988. In recognition of the technology's successful commercialization, researchers at PNL received a citation for Excellence in Technology Transfer from the Federal Laboratory Consortium in 1991. 
In late 1991, the Buildings Energy Program initiated a Speaker Series. Through this program, individuals from various buildingsrelated organizations are invited to speak at PNL and spend time with staff researchers. The goal of the Speaker Series is to facilitate information exchange between research organizations. During 1991, a representative from the Lighting Design Lab in Seattle visited PNL as part of this series.
During 1991, staff made presentations at several conferences and published a number of papers in various publications. A complete list of these presentations and publications is provided at the back of this report.

For more information on PNL's technology deployment efforts, contact

Dlana L. Shankle

509/376-4157 


\section{University Relations}

Working with key universities is an important aspect of PNL's activities in the Buildings Energy Program. In the Building System Integration Program, PNL collaborated with the University of Oregon and California Polytechnic State University to develop AEDOT Prototype 1. The possibility of adding the Carnegie Mellon University/ Industry CAD Consortium to the project team is being investigated. Through the Northwest College and University Association for Science (NORCUS) program. a faculty member from Oregon State University was involved in the Targets Project.

During FY91, seven students were hosted for 3 months to work on program and project activities. These students represented the following universities and departments:

Washington State University at Tri-Cities, Computer Sciences and Mechanical Engineering Departments

- Untversity of Oregon, Physics Department
- Portland State University, Mechanical Engineering Department

n University of California, Los Angeles, Environmental Sciences Department

- Southern University, Mechanical Engineering Department and School of Architecture.

PNL has participated in the LONEStar monitoring and evaluation program being managed for the State of Texas by Texas A\&M University in College Station. PNL brings to this collaboration its extensive experience in monitoring and analyzing energy use in buildings. Other opportunities for cooperative efforts are being identified.

For more information on PNL's collaborations with universities, contact

R. Eric Leber

509/375-2730 



\section{Energy Technology Development Initiative}

The objective of PNL's Energy Technology Development Initiative is to continually strengthen the Laboratory's energy research capabilities and bring these to bear in selected areas that have significant potential for meeting national energy needs. The Laboratory's capabilities are strengthened through investments in exploratory research and in the hiring and training of key staff. Collaborative relationships with industry are also established in specific technological areas to ensure that the research is relevant and to increase the likelihood of commercial success. Investments are undertaken in key areas consistent with DOE's energy missions.

Currently, investments are focused primarily on improving the energy efficiency of buildings, industrial processes, vehicles, and utility systems. Of particular interest to the bulldings sector are the System Diagnostics and Operations activity and the Resource Confirmation activity.

\section{System Diagnostics and Operations}

The objective of the System Diagnostics and Operations activity is to develop, demonstrate, and transfer to industry advanced computerbased systems to Improve the operating efficiency of energy systems. In cooperation with industry, PNL is exploring innovative approaches to system operations. These approaches include use of advanced sensors and computational techniques (e.g., qualitative reasoning, machine learning, and sophisticated user interfaces).
During FY91, exploratory research was undertaken to combine these approaches in a prototype of an automated diagnostician for commercial building HVAC systems. Efforts are under way to establish CRADAs with private sector firms. Development work on the HVAC diagnostician will continue, and the prototype will be demonstrated in FY92.

\section{Resource Confirmation}

The objective of the Resource Confirmation activity is to demonstrate and test emerging energy-efficiency and renewable technologies that appear to have significant potential. Once validated, these resources can be included in regional resource supply curves and plans.

The focus of this activity during FY91 involved working with Bonneville to define a collaborative process for identifying and undertaking demonstration projects that would involve Pacific Northwest utilities, state energy offices, industrial partners, and national laboratories. Bonneville and DOE have agreed to collaborate on developing a model process and generic technology characterization data that can be transferred from the Pacific Northwest to other regions.

Plans for FY92 call for one or more quickstart demonstration projects in areas that appear to have significant resource potential. At the same time, regional stakeholders and DOE will screen and select technologies for future demonstration, some of which will likely involve building technologies.

For more information on the Energy Technology Development Initiative. contact

Bobi A. Garrett 509/376-4665 


\section{Contacts}

\section{Presentations}

\section{Publications}

Acronyms and Abbreviations 


\section{Contacts}

\section{Energy Programs}

Irvin L. (Jack) White Battelle Washington Office 370 L'Enfant Promenade, Suite 900 901 D Street SW

Washington, DC 20024

202/646-7783

\section{U.S. Department of Energy Programs}

Thomas J. Secrest

Pacific Northwest Laboratory

P.O. Box 999, K5-02

Richland, WA 99352

509/375-3873

\section{Bullding System Integration Program}

Michael R. Brambley

Pacific Northwest Laboratory

P.O. Box 999, K5-16

Richland, WA 99352

509/375-6875

\section{Bullding Energy Standards Program}

Ronald E. Jarnagin

Pacific Northwest Laboratory

P.O. Box 999, K5-02

Richland, WA 99352

509/375-3813

Federal Energy Management Program

J. William Currie

Pacific Northwest Laboratory

P.O. Box 999, K7-82

Richland, WA 99352

:509/375-3969

Economics and Systems Analysis Program

Andrew K. Nicholls

Battelle Washington Office

370 L'Enfant Promenade, Suite 900

901 D Street SW

Washington, DC 20024

202/646-5238

\author{
Bulldings Equipment Technology \\ Assessment Program \\ Bruce R. Kinzey \\ Battelle Washington Office \\ 370 L'Enfant Promenade, Suite 900 \\ 901 D Street SW \\ Washington, DC 20024 \\ 202/646-5231
}

\section{Support to Pacific Gas and Electric Company's ACT' ${ }^{2}$ Project \\ Drury Crawley \\ Pacific Northwest Laboratory \\ P.O. Box 999, K5-06 \\ Richland, WA 99352 \\ 509/375-6367}

\section{Bonneville Power Administration Programs}

Thomas J. Foley

Battelle Portland Office

500 N. Multnomah, Suite 650

Portland, OR 97232

503/230-4777

Regional End-Use Metering Program

William F. Sandusky

Pacific Northwest Iaboratory

P.O. Box 999, K5-06

Richland, WA 99352

509/375-3709

Manufactured Housing Technical

Transfer Project

Allen D. Lee

Battelle Portland Office

500 N. Multnomah, Suite 650

Portland, OR 97232

503/230-7584

Residential Fuel Choice Project

Allen D. Lee

Battelle Portland Office

500 N. Multnomah, Suite 650

Portland, OR 97232

503/230-7584 
Evaluation Research Assistance Project

W. Michael Warwick Battelle Portland Office 500 N. Multnomah, Suite 650

Portland, OR 97232

503/230-4650

\section{Energy Edge Program}

William F. Sandusky

Pacific Northwest Laboratory

P.O. Box 999, K5-06

Richland, WA 99352

509/375-3709

Tacoma Multifamily End-Use

Monitoring Project

William F. Sandusky

Pacific Northwest Laboratory

P.O. Box 999, K5-06

Richland, WA 99352

509/375-3709

Equivalent Thermal Parameters Project

Robert G. Pratt

Pacific Northwest Laboratory

P.O. Box 999, K5-08

Richland, WA 99352

509/375-3648

Resource Supply Expansion Program

W. Michael Warwick

Battelle Portland Office

500 N. Multnomah, Suite 650

Portland, OR 97232

$503 / 230-4650$

\section{Other Federal Agency Programs}

J. William Currie

Pacific Northwest Laboratory

P.O. Box 999, K7-82

Richland, WA 99352

509/375-3969
Private Client Programs and Projects

Thomas J. Secrest

Pacific Northwest Laboratory

P.O. Box 999, K5-02

Richland, WA 99352

509/375-3873

\section{Technology Deployment}

Diana L. Shankle

Pacific Northwest Laboratory

P.O. Box 999, K6-54

Richland. WA 99352

509/376-4157

\section{University Relations}

\section{R. Eric Leber}

Pacific Northwest Laboratory

P.O. Box 999, K1-64

Richland, WA 99352

509/375-2730

\section{Energy Technology Development Initiative}

Bobi A. Garrett

Pacific Northwest Laboratory

P.O. Box 999, K6-52

Richland, WA 99352

509/376-4665 


\section{Presentations}

Baechler, M. C., and A. D. Lee. "Implications of Environmental Externalities Assessments for Solar Thermal Powerplants." Presented at the 1991 ASME-JSME International Solar Energy Conference, Reno, Nevada, March 17-22, 1991.

Brambley, M. R., and J. B. Pohl. "Artificial Intelligence in Intelligent Building Design." Presented at the Second Annual International Conference on Intelligent Buildings: Future Build 2001. Intelligent Bulldings Institute, Washington, D.C.

Crawley, D. B. "The ACT ${ }^{2}$ Project: Demonstration of Maximum Energy Efficiency in Real Buildings." Presented at the Advanced Commercial Building Program (C-2000) Workshop, Vancouver, British Columbia, Canada, October 23, 1991.

Crawley, D. B. "The ACT ${ }^{2}$ Project." Presented at the Fall 1991 Meeting of the Western States Load Research Group. Phoenix. Arizona, October 9, 1991.

Crawley, D. B. "Energy Technologies: A Preview of the 90s." Keynote presentation to the St. Louis Chapter, American Society of Heating, Refrigerating and Air-Conditioning Engineers, Inc., HRATEC '91, St. Louls, Missouri, March 26, 1991.
Crawley, D. B. "The U.S. Experience with Energy Conservation in Buildings: What's Worked and What Hasn't." Presented to the Energy Research Institute, USSR Academy of Sciences, Moscow, Russia, June 3, 1991, and to the Moscow International Energy Club, Presidium, USSR · Academy of Sciences, Moscow, Russia, June 6, 1991.

Hadley, D. L., S. A. Bailey, and G. B. Parker. "Ventilation and Moisture in New EnergyEfficient Manufactured Homes." Presented to the Air and Waste Management Association 84th Annual Meeting, Vancouver, British Columbia, June 16-21, 1991.

Sandusky, W. F. “Adventures in Running End-Use Metering Programs." Presented at the Northwest Public Power Association 1st Annual Symposium on End-Use . Metering, Portland, Oregon, May 14-16. 1991.

Sandusky, W. F., D. D. Hostetler, and J. D. Schwab. "An Improved Data Pipeline for End-Use Metering Activities." Presented at the 1991 Fall Meeting of the Western States Load Research Group, Phoenix, Arizona, October 9, 1991. 



\section{Publications* $^{*}$}

Baechler, M. C., A. D. Lee, and R. G. Lucas. 1991. CAPS Quick Reference Gulde,

- Version 1.1. PNL-7741, Pacific Northwest Laboratory, Richland, Washington.*

Brambley, M. R., and M. L. Bailey. 1991. "The U.S. Department of Energy's Advanced Energy Design and Operation Technologies (AEDOT) Project." In First International Symposium on Building Systems Automation-Integration Conference Notebook. College of Engineering, University of Wisconsin-Madison/Extension, Madison, Wisconsin. PNL-SA-19048.*

Briggs, R. S., and M. R. Brambley. 1991. "Whole-Building Energy Targets: A Methodology for Future Performance-Based Standards." In Building Simulation '91 Conference Proceedings, eds. J. A. Clarke, J. W. Mitchell, and R. C. Van de Perre, pp. 631-637. International Building Performance Simulation Association, Sophia-Antipolis, Nice, France.

PNL-SA-18835.*

Briggs, R. S. 1992. An Energy and Economic Performance Assessment of Central and Floor-by-Floor HVAC Systems in Office Buildings. GRI-92/0093, Gas Research Institute, Chicago, Illinois.

Briggs, R. S., D. B. Crawley, and J. S. Schllesing. 1992. Energy Requirements for Office Butldings, Volume 1, Existing Buildings. GRI-90/0236.1, Gas Research Institute, Chicago, Illinois.
Callaway, J. W., A. G. Thurman, and D. L. Shankle. 1991. Adoption, Implementation, and Enforcement of Commercial Bullding Energy Codes in New Mexico and Arizona. PNL-7712, Pacific Northwest Laboratory. Richland. Washington.*

Crawley, D. B. 1991. Recommendations for Adapting ASHRAE/IES Standard 90.11989 for Canada. PNWD-1812, Battelle. Pacific Northwest Laboratories, Richland, Washington.

Crawley, D. B., and J. J. Boulin. 1991. "ENVSTD: A Computer Program for Complying with Bullding Envelope Requirements." In VTT Symposium 125 Proceedings, Computers and Building Regulations, eds. Kalle Kahkonen and Bo-Christer Bjork, pp. 65-76. Statens Tekniska Forskningscentral (VTT Technical Research Centre of Finland). Tapiola, Espoo, Finland. PNL-SA-19374.*

Crawley, D. B., and B. L. Krieg. 1991. "The $\mathrm{ACT}^{2}$ Project: Demonstration of Maximum Energy Efficiency in Real Buildings." In Bulldings for the 21st Century. pp. 12.1-12.9. Second CIBSE Australia Conference, Sydney, NSW, Australia. PNL-SA-19886.*

Crawley, D. B., and J. S. Schliesing. 1992. Energy Requirements for Office Buldings, Volume 2, Recent and Future Buildings. GRI-90/0236.2, Gas Research Institute, Chicago, mlinois.

Currie, J. W., R. W. Reilly, R. W. Brancato, and J. A. Dirks. 1991. "Modernizing Federal Energy Systems: The FEDS Development Approach." Energy Engineering 88(4):6-19.

\footnotetext{
Reports and articles marked with asterisks are available to DOE and DOE Contractors from the Office of Scientific and Technical Information, P.O. Box 62, Oak Ridge, TN 37831. Copies are available to the public from the National Technical Information Service, 5285 Port Royal Rd., Springfield, VA 22168.
} 
Hadley, D. L. 1991. Characterization of Commercial Load Shapes by Weather Day Type. PNL-7419, Pacific Northwest Laboratory, Richland, Washington.*

Jarrell, D. B., M. K. Drost, R. C. Stratton, M. Hoza, E. J. Eschbach, L. L. Larson, and F. V. DiMassa. 1991. Marine Corps Air-Ground Combat Center, Twenty-Nine Palms, California, Central Heating Plant Characterization Report. PNL-7672, Pacific Northwest Laboratory, Richland, Washington.*

Lee, A. D. 1991. "Interactions Between Residential Efficiency Standards and Fuel Choice." In Energy Program Evaluation: Uses, Methods, and Resuitts. National Energy Program Evaluation Conference, Chicago, Illinois, August 21-23, 1991. PNL-SA-19495.*

Lee, A. D. 1991. "Northwest HUD-Code Manufacturers Expand Production of Energy-Efficient Homes." Automated Builder, pp. 27-28.

Lee, A. D., M. C. Baechler, F. V. DiMassa, R. G. Lucas, and D. L. Shankle. 1991. Demonstration of the DOE Interim Energy Conservation Standards for New Federal Residential Buildings-Executive Summary. PNL-7955, Pacific Northwest Laboratory, Richland, Washington.*

Lee, A. D., M. C. Baechler, F. V. DiMassa, R. G. Lucas, and D. L. Shankle. 1991. Demonstration of the DOE Interim Energy Conservation Standards for New Federal Residential Buildings. PNL-7956, Pacific. Northwest Laboratory, Richland, Washington.*
Lee, A. D., J. E. Englin, and C. L. Bruneau. 1991. Interactions Between Fuel Choice and Energy Efficiency in New Homes in the Pacific Northwest. PNL-7592, Pacific Northwest Laboratory, Richland, Washington.*

Lee, A. D., R. G. Lucas, and C. C. Conner. 1990. Comparison of the Economic Effects of Three Residential Energy Codes on Home Buyers. Prepared for Mineral Insulation Manufacturers Association, Alexandria, Virginia. Battelle, Pacific Northwest Laboratories, Richland, Washington.

Lucas, R. G. 1991. Supplementary Technical Support Document for COSTSAFR Version 1.1. PNL-7742, Pacific Northwest Laboratory, Richland, Washington.*

Lucas, R. G., L. Connell, and A. D. Lee. 1991. Conservation Optimization Standard for Savings in Federal Residences (COSTSAFR) COSTSAFR 3.1 - User's Manual. PNL-7743, Pacific Northwest Laboratory, Richland, Washington.*

Lucas, R. G., and A. D. Lee. 1991. Point System User's Guide: Paper Point System and Computerized Automated Point System (CAPS)-Version 1.1. PNL-7261 Rev. 1, Pacific Northwest Laboratory, Richland, Washington.*

Miller, N. E., E. W. Pearson, G. M. Stokes, R. G. Pratt, M. A. Williamson, and J. S. Roberts. 1991. Characterizing Residential Thermal Performance from High Resolution End-Use Data - Volume 1: Methodology. PNL-7590 Vol. 1, Pacific Northwest Laboratory, Richland, Washington.* 
Mtller, N. E., M. A. Williamson, S. A. Bailey, R. G. Pratt, G. M. Stokes, W. F. Sandusky, E. W. Pearson, and J. S. Roberts. 1991. Characterizing Residential Thermal Performance from High Resolution EndUse Data - Volume 2: Analysis. PNL-7590 Vol. 2, Pacific Northwest Laboratory, Richland, Washington.*

O'Neill, P. J., D. B. Crawley, and J. S. Schliesing. 1991. "Using Regression Equations to Determine the Relative Importance of Inputs to Energy Simulation Tools." In Building Simulation '91 Conference Proceedings, eds. J. A. Clarke, J. W. Mitchell, and R. C. Van de Perre, pp. 283289. International Building Performance Simulation Association, Sophia-Antipolis, Nice, France. PNL-SA-19436.*

Parker, G. B., and J. W. Currie. 1991. Mobile Energy Laboratory Energy-Effictency Testing Program - Semiannual Report: October 1, 1990, Through March 31, 1991. PNL-7793, Pacific Northwest Laboratory. Richland, Washington.*

Parker, G. B., and J. L. Heller. 1991. "Measuring Energy Efficiency Improvements with the Mobile Energy Laboratories." Energy Engineering 88(4):36-49.

Pratt, R. G., C. C. Conner, M. K. Drost, N. E. Miller, B. A. Kooke, M. A. Halverson, B. A. LaBaron, R. G. Lucas, J. Joe, E. E. Richman, K. G. Ritland, W. F. Sandusky, M. E. Taylor, and S. G. Hauser. 1991. Significant ELCAP Analysis Results: Summary Report. PNL-6659, Pacific Northwest Laboratory, Richland, Washington.*

Pratt, R. G., and B. A. Ross. 1991. Measured Electric Hot Water Standby and Demand Loads from Pacific Northwest Homes. PNL-7889, Pacific Northwest Laboratory. Richland, Washington.*
Ross, B. A. 1991. Analysis of Residential Refrigerator/Freezer Performance. PNL-7656, Pacific Northwest Laboratory, Richland, Washington.*

Schliesing, J. S., D. B. Crawley, and N. Shrivastava. 1992. Analysis of the Impacts of Revised Building Standards on Bullding Energy Consumption and Demand. GRI91/0196, Gas Research Institute, Chicago, Illinois.

Secrest, T. J., J. W. Currie, J. G. DeSteese, J. A. Dirks, T. J. Marseille, G. B. Parker, E. E. Richman, and S. A. Shankle. 1991. Fort Lewis Electric Energy Baseline and Efficiency Resource Assessment. PNL-7763, Pacific Northwest Laboratory, Richland, Washington.*

Shankle, D. L., T. J. Marseille, S. A. Weakley, A. R. Anderson, and R. L. Eckert. 1991. Market Assessment of Floor-by-Floor HVAC Equipment GRI-91/0175, Gas Research Institute, Chicago, Illinois.

Shankle, D. L., A. G. Thurman, and J. W. Callaway. 1991. "Adoption, Implementation. and Enforcement of Commercial Building Energy Codes in Arizona and New Mexico." In 5th National Demand-Side Management Conference, Boston, Massachusetts, July 30 - August 1, 1991. PNL-SA-19162.*

Shankle, D. L., A. G. Thurman, and J. W. Callaway. 1991. "Building Energy Codes and Standards: A Complement to Demand-Side Management Programs." In Demand-Side Management and the Global Environment. Arlington, Virginia. PNL-SA-18598.* 
Taylor; M. E., K. G. Ritland, and R. G. Pratt. 1991. Hot Water Electric Energy Use in Single-Family Residences in the Pacific Northwest. DOE/BP-13795-27, Bonneville Power Administration, Portland, Oregon.*

Vine, E., and D. Crawley, eds. 1991. State of the Art of Energy Efficiency: Future Directions. American Council for an Energy-Efficient Economy, Washington, D.C.

Vine, E., D. Crawley, and P. Centolella, eds. 1991. Energy-Efficiency and the Environment: Forging the Link. American Council for an Energy-Efficient Economy, Washington, D.C.
Weijo, R. O., A. K. Nicholls, S. A. Weakley, R. L. Eckert, D. L. Shankle, M. R. Anderson, and A. R. Anderson. 1991. Evaluation of the Near-Term Commercial Potential of Technologies Being Developed by the Office of Building Technologies: Volume I - Screening of Technologies. PNL-6778 Vol. I, Pacific Northwest Laboratory, Richland, Washington.*

Weljo, R. O., A. K. Nicholls, S. A. Weakley, R. L. Eckert, D. L. Shankle, M. R. Anderson, and A. R. Anderson. 1991. Evaluation of the Near-Term Commercial Potential of Technologies Being Developed by the Office of Building Technologies: Volume II - Survey Results. PNL-6778 Vol. II, Pacific Northwest Laboratory, Richland, Washington.* 


\title{
Acronyms and Abbreviations
}

\author{
ACT ${ }^{2} \quad$ Advanced Customer Technology Test for Maximum Energy Efficiency \\ AEDOT Advanced Energy Design and Operation Technologies \\ ASHRAE American Society of Heating, Refrigerating and Air-Conditioning Engineers, Inc. \\ Battelle . Battelle, Pacific Northwest Laboratories \\ BESP Building Energy Standards Program \\ BETA . Buildings Equipment Technology Assessment \\ Bonneville Bonneville Power Administration \\ BSIP Building System Integration Program \\ CAD computer-aided design \\ CFC chlorofluorocarbon \\ CRADA Cooperative Research and Development Agreement \\ DOE U.S. Department of Energy \\ ELCAP End-Use Load and Consumer Assessment Program \\ ESAP Economics and Systems Analysis Program \\ ETP equivalent thermal parameters \\ FEDS Federal Energy Decision Screening \\ FEMP Federal Energy Management Program \\ FY fiscal year \\ GRI Gas Research Institute \\ HUD U.S. Department of Housing and Urban Development \\ HVAC heating, ventilating, and air-conditioning
}


ISS

Illuminating Engineering Society of North America

Mima Mineral Insulation Manufacturers Association

MCS Model Conservation Standard

MEC Model Energy Code

MEL Mobile Energy Laboratory

NAIMA North American Insulation Manufacturers Association

NES National Energy Strategy

NORCUS Northwest College and University Association for Science

NWPPC Northwest Power Planning Council

OBT Office of Building Technologies

PEPCO Potomac Electric Power Company

PG\&E Pacific Gas and Electric Company

PNL Pacific Northwest Laboratory

.PP\&L Pennsylvania Power \& Light Company

R\&D research and development

REMP Regional End-Use Metering Program

RCDP Residential Construction Demonstration Project

RSEP Resource Supply Expansion Program

Targets Whole-Building Energy Targets Project

TPU Tacoma Public Utilities 